\title{
Corrigendum: Firing clamp: a novel method for single-trial estimation of excitatory and inhibitory synaptic neuronal conductances
}

\author{
Anton V. Chizhov ${ }^{1}$, Evgenya Malinina ${ }^{2}$, Michael Druzin ${ }^{2,3}$, Lyle J. Graham ${ }^{4 *}$ and Staffan Johansson ${ }^{2}$ \\ ${ }^{1}$ Computational Physics Laboratory, Division of Plasma Physics, Atomic Physics and Astrophysics, A.F. Ioffe Physical-Technical Institute of the Russian Academy of \\ Sciences, St. Petersburg, Russia \\ ${ }^{2}$ Department of Integrative Medical Biology, Umea University, Umea, Sweden \\ ${ }^{3}$ Department of Neurodynamics and Neurobiology, Lobachevsky State University of Nizhny Novgorod, Nizhny Novgorod, Russia \\ ${ }^{4}$ Neurophysiology and New Microscopies Laboratory, Centre National de la Recherche Scientifique, Université Paris Descartes, Paris, France \\ ${ }^{*}$ Correspondence: Iyle@biomedicale.univ-paris5.fr
}

Edited and reviewed by:

Egidio D’Angelo, University of Pavia, Italy

Keywords: synaptic conductance estimation, dynamic clamp, firing-clamp, neuron models, neurophysiology

\section{A corrigendum on}

Firing clamp: a novel method for single-trial estimation of excitatory and inhibitory synaptic neuronal conductances

by Chizhov, A. V., Malinina, E., Druzin, M., Graham, L. J., and Johansson, S. (2014). Front. Cell. Neurosci. 8:86. doi: 10.3389/ fncel.2014.00086

It is important to note that Bédard and colleagues have also described a method for the single trial extraction of synaptic input (Bédard et al., 2012). This method, which requires that the membrane voltage remains subthreshold, thus in a linear domain, obtains an estimate for synaptic inputs based on time derivatives of passive recordings of the membrane voltage trace, i.e., without perturbations from injected current by the amplifier.

\section{REFERENCES}

Bédard, C., Béhuret, S., Deleuze, C., Bal, T., and Destexhe, A. (2012). Oversampling method to extract excitatory and inhibitory conductances from single-trial membrane potential recordings. J. Neurosci. Methods 210, 3-14. doi: 10.1016/ j.jneumeth.2011.09.010

Conflict of Interest Statement: The authors declare that the research was conducted in the absence of any commercial or financial relationships that could be construed as a potential conflict of interest.
Received: 01 May 2014; accepted: 08 May 2014; published online: 28 May 2014.

Citation: Chizhov AV, Malinina E, Druzin M, Graham LJ and Johansson S, (2014) Corrigendum: Firing clamp: a novel method for single-trial estimation of excitatory and inhibitory synaptic neuronal conductances. Front. Cell. Neurosci. 8:149. doi: 10.3389/fncel. 2014.00149

This article was submitted to the journal Frontiers in Cellular Neuroscience.

Copyright (C) 2014 Chizhov, Malinina, Druzin, Graham and Johansson. This is an open-access article distributed under the terms of the Creative Commons Attribution License (CC BY). The use, distribution or reproduction in other forums is permitted, provided the original author(s) or licensor are credited and that the original publication in this journal is cited, in accordance with accepted academic practice. No use, distribution or reproduction is permitted which does not comply with these terms. 